\title{
The Impact of the University Students' Level of Alienation on their Perception of General Satistaction
}

\author{
İlhan Kaçire ${ }^{1}$ \\ ${ }^{1}$ Dicle University, Ziya Gökalp Education Faculty, Educational Sciences Departrment, Sur / Diyarbakır, Turkey \\ Correspondence: İlhan Kaçire, Dicle University, Ziya Gökalp Education Faculty, Educational Sciences Departrment, \\ Sur / Diyarbakır, Turkey. E-mail: ilhankacire@gmail.com
}

Received: September 18, 2015

Accepted: October 26, 2015

Online Published: October 30, 2015

doi:10.5430/ijhe.v5n1p38

URL: http://dx.doi.org/10.5430/ijhe.v5n1p38

\begin{abstract}
The purpose of this study is to investigate the impact of university students' level of alienation on their general satisfaction. The study was carried out using rational screening model. The total participants of this study were 551 Dicle University students, studying at Medical, Technology, and Ziya Gökalp Education Faculty departments. The "alienation" and "general satisfaction" scales were used in data collection process. The collected data were analyzed by structural equation modeling. The fit index of the model was confirmed to be within the range of standard value. It was found that the university students' level of alienation had explained $52 \%$ of their perception of general satisfaction. Concerning the findings of the current paper, it can be claimed that it is of significant importance for the universities aiming at increasing general satisfaction of students to develop sustainable policies preventing alienation and to manifest back office applications.
\end{abstract}

Keywords: Alienation, General satisfaction, University

\section{Introduction}

Alienation is a concept found its place in the very beginning of humanity on the earth, experienced at every stage of civilization throughout history and as a consequence of its nature, will certainly be seen in upcoming processes, as well (Avci 2012). However, in the context of higher education, the idea of student alienation became widespread in response to the student unrest of the late 1960s (Case, 2007).

It can be claimed that early studies on alienation experienced in educational areas were fundamentally carried out on black and white students or on those with different ethnic backgrounds and their concern was predominantly dropout from the school (Moyer and Motta, 1982; Suen, 1983; Loo and Rolison, 1986; Valverde, 1987; Steward, Jackson and Jockson, 1990; Calabrese and Poe, 1990; Thompson and Fretz, 1991; Loughrey and Harris, 1992; Steward, Germain and Jackson, 1992; Cabrera and Nora, 1994). Later different studies were conducted on alienation and the concept was handled either alone or associated with a number of issues such as student participation, school culture, dropout from the school, social acceptance, and academic success (Duru, 1995; Travis, 1995; Shoho, 1996; Cecen, 2006; Case, 2008; Lewis, 2009; Hascher and Hagenauer, 2010; Hands and Warshak, 2011; Bekhet, Elguenidi and Zauszniewski, 2011; Çağlar, 2012; Erimez, 2012). While the primary focus of foreign studies conducted on alienation was racism, it was the study of solitude and attitude for those carried out in Turkey (Atas \& Ayik, 2013).

Alienation is phenomena effecting organizations and human relations (Tezcan, 1991). Research findings on alienation in different organizational settings seem to suggest that alienation is an outcome of frustration situation (Yadaw \& Nagle, 2012). ). It can be said that the early studies on alienation were more concerned about the estrangement of the employee and employer. In this sense, it can be said that the concept was profoundly tackled through studies in business organizations. Basically, it is possible to claim that alienation has effected educational organizations increasingly similar with the case in profit making companies (Tezcan, 1991). It is indicated that alienation has a negative effect on educational organizations in terms of some significant outputs such as students' attitude towards teaching profession (Erbas, 2014; Çaglar, 2012), discrimination and prejudice (Cabrera \& Nora, 1994), academic success (Hascher \& Hagenauer, 2010; Johnson, 2005). Moreover, Roeser, Lord \& Eccles found out that alienation from the middle school has a negative relation with the general satisfaction. In this sense, alienation from the university has a negative relation with their general satisfaction. 
Alienation means, for Marx, that man does not experience himself as the acting agent in his grasp of the world, but that the world (nature, others, and himself) remain alien to him. They stand above and against him as objects, even though they may be objects of his own creation (Fromm, 1955). Marx defines the concept not only as the man alienated from his own act of creation, but also, from life, himself and others surrounding him (Fromm, 1973; Nettler, 1957). However, Marx uses the concept alienation as the weakening of worker initially and accepts labor as the chief underlying effect of alienation (Nettler, 1957). It can be said that Marx defines alienation under two subthemes: the estrangement of man from the environment and from the self. It is a fact that the definitions of alienation put forward later were affected by that of Marx. In some studies alienation was defined as the isolation of the mere man from the others. Nevertheless, it was Seeman who put forward the socio-psychological and the widespread definition of the concept in literature (1959). Seeman, observing the individual alienation of man living in a society, asserts that alienation includes the following five fundamental dimensions: powerlessness, meaningfulness, formlessness, isolation and self-estrangement. Geyer (2001) urges that alienation has taken new forms in the postmodern world, particular with regard to conditions of increased complexity and informational overload (Case, 2007).

Korman (1981), stating that alienation essentially compromises dispersement and estrangement claims that there are two kinds of alienation: The individual alienation which is the first kind includes a difference (discrepancy) between one's daily behaviors and his sense of self. The second kind, social alienation, means standing apart from the others and having lack of a common communication. Lang (1985) defines the concept estrangement as either the dispersement of the man from his needs or from the people both in and out of his domain. However, there are a number of researchers defining alienation as disappointment or uneasiness such as (Hoy, Blazovsky \& Newland, 1983; Hirschfeld \& Feild, 2000). It is defined by Hoy, Blazovsky \& Newland (1983) as the disappointment of worker about his status. In the current study, the concept is discussed as both the disappointment of the individual and his undergoing a feeling of estrangement as a result.

In the related literature, alienation is viewed as estrangement from the work. Hirschfeld and Feild (2000) define the concept as being not concern with the business world. Estrangement from the work appears as a psychological phenomenon experienced by the worker in his inner world (Kanungo, 1979; Hirschfeld, Feild \& Bedeian, 2000). Alienation occurs as workers are estranged from themselves when the meanings and purposes of their work are lost (Gaidzanwa, 2007). In the current study, alienation is viewed within the concept adapting its use in business organizations to educational areas. In other words, it is the feeling of disappointment or dispersement from university. Concerning the education, alienation is the estrangement and dispersement of staff and learners at schools even the parents from the work they are to fulfill (Erjem, 2005). As for Rodriguez (1997), "Some students are lost; for they face unknown enemies and dangers just as soldiers in a war. Students get lost or alienate when they are unprepared about a stranger's claims and hostile settings. Alienation experienced in educational organizations can be defined as compromising the state of disappointment or dispersement as viewed in business organizations. Alienation occurring as withdrawal/dispersement represents a case of the dramatically decline of thought towards school identity, progressive emotion and distractibility from academic goal and values (Hascher \& Hagenauer, 2010). Concerning the education, alienation is the estrangement and dispersement of staff and learners at schools event parents from the work they are to fulfill. Alienation in education and its forms are related to school education (Erjem, 2005).

The received education, qualifications of the teacher and classroom interaction are not the mere factors effecting general satisfaction. It depends not only on the harmony between the campus environment and students' characteristics (Borden, 1995), but also on academic quality of the institution, the accessibility of lecturers, a not competitive learning environment, small sized classes, explanatory evaluations, excellence of the program, a different syllabus, and a highly qualified education (Loo \& Rolison, 1986). As stated by Elliot and Shin (2002) student satisfaction is shaped by constantly repeating experiences in campus life. Besides, campus environment is web of interdependent experiences effecting and surrounding the entire satisfaction of students apparently. It can be claimed that the factors effecting general satisfaction are similar with those of effecting alienation. In this case, it is not difficult to say that the general satisfaction of the students alienated from university as a result of both the weak quality of education and lecturers and routinized and boring campus life will decline naturally.

The view of an alienated individual towards the self is blurred in some extent. Thus, it is quite difficult for an individual exhausted from the environment and his inner world and experiencing the feeling of disappointment to be content with their surrounding environment. If the actions in educational institutions get monotonous, the staff become desperate, their peers insincere and students themselves discontent. In this sense, some express their feelings by withdrawal or challenging the conditions. To illustrate, alienated students can easily deny public schools norms in a way beneficial to their peers or counter-school (Mau, 1992). Alienated students tend to exert relatively little effort on their studies and to be rewarded with lower grades, although cause and effect may be uncertain here. Albeit 
Sparse, reveals that alienated students admit more frequent acts of antisocial conduct such as vandalism (Carrington and Conley, 1977).

\subsection{Hypotheses of the Research}

In accordance with literature stated above, it is supposed that alienation level of university students effects their perception of general satisfaction. Two hypotheses are formed to test this effect. These are;

$\mathrm{H}_{1}$ : The alienation level of university students effects their perception of general satisfaction in a negative way.

$\mathrm{H}_{2}$ : The alienation level of university students explains their perception of general satisfaction significantly.

\section{Method}

\subsection{Research Design}

The study was carried out using rational screening model. Relational screening model is research design aiming at determines the existence and level of variance between two or more variables (Karasar, 2009).

\subsection{Participants}

The study was carried out using rational screening model. 551students, studying at Ziya Gökalp Educational, Medical and Theology faculties, Dicle University, forms the population of the study Upon forming the structural equation modeling, if the number of samples are fewer than 100 it is called small, within 100 and 200 medium and larger than 200 ones are called large sampling (Bayram, 2013). Within this scope, it can be said that the size of study group is sufficient. While $35.9 \%$ of the study group were male, $61.8 \%$ were female, $(2.2 \%$ unstated); $34.6 \%$ were first grade, $31.7 \%$ second grade, $5.2 \%$ third and $25.1 \%$ were fourth grade students (3.4\% unstated).

\subsection{Data Collection Tools}

Alienation Scale: The scale designed by Kurtulmus, Kacire, Karabıyık and Yigit (2015) was developed to measure the level of alienation university students. The Cronbach Alpha internal consistency level of the scale consisting of a single factor is 0.85. However, in the current study, Cronbach Alpha internal consistency level of alienation scale is found to be 0.84 . The Likert type scale consists of 9 items stating "I strongly agree (5)" to "I strongly disagree" (1)". "I think my life in this university got routinized." can be given as an example to illustrate the scale. In this paper, confirmatory factor analysis was carried out and the fit index of the model $(x 2=54.820 ; \mathrm{df}=25 ; x 2 / \mathrm{df}=2.19$; RMSEA=0.04; AGFI $=0.96$; GFI $=0.97$; $\mathrm{CFI}=0.98$ ) was confirmed to be within the range of standard value. The path diagram of the scale is shown in figure 1.

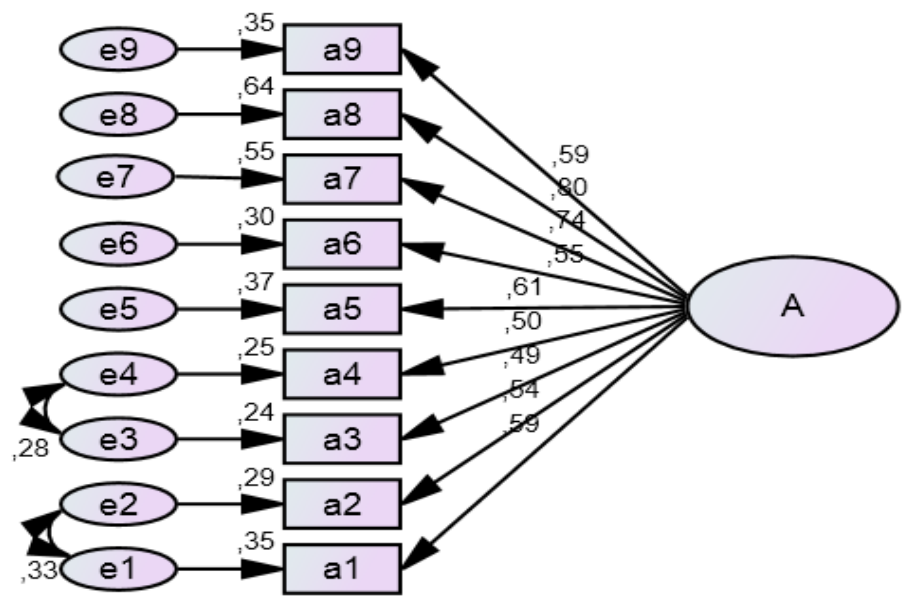

Figure 1 . The path diagram of the alienation scale

Figure 1 Shows that the scale is single factored and the factor load of the scale items is within 0.49 and 0.80 .

The General Satisfaction Scale: The scale developed by Sheau-yuen Yeo (2006) to measure the satisfaction of students towards educational institutions, is single factored. The Cronbach Alpha internal consistency level of the scale is 0.91 . However, in the current study, it was found to be 0.88 . The scale is a likert type consisting of 6 items developed to measure the perception of general satisfaction. "I am happy to be a student at this university" can be given as an example. . In this paper, confirmatory factor analysis was carried out and the fit index of the model 
$(x 2=18.306 ; \mathrm{df}=7 ; \varkappa 2 / \mathrm{df}=2.61 ; \mathrm{p}=0.011 ; \mathrm{RMSEA}=0.05 ; \mathrm{AGFI}=0.97 ; \mathrm{GFI}=0.99 ; \mathrm{CFI}=0.99$ was confirmed to be within the range of standard value. The path diagram of the scale is shown in figure 2 .

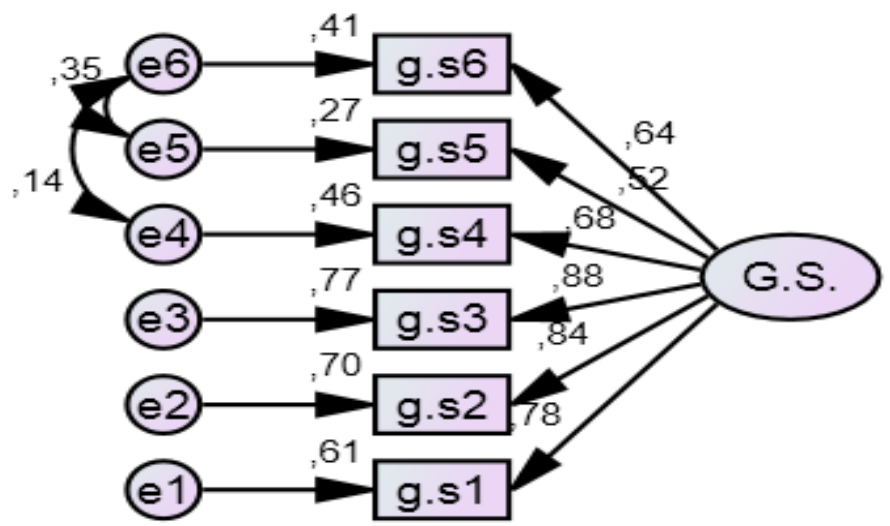

Figure 2. The path diagram of the overall satisfaction scale

Figure 2 shows that the scale is single factored and the factor load of the scale items is within 0.48 and 0.66.

\subsection{Data Analysis}

Providing the assumption regarding the results of multivariate statistical techniques, data obtained from the scales were analyzed. The assumptions in relation with multivariate statistical techniques are single variant normal distribution, extreme values, multivariate normal distribution, and linearity. The coefficient of kurtosis and skewness were considered for single variant normal distribution.

The kurtosis and skewness value of the alienation scale were 0.03 and -0.77 respectively. The kurtosis and skewness value of the overall satisfaction scale were 0.165 and -0.68 respectively. That the skewness and kurtosis values of the scales are within the range of \pm 1 , it can be said that the data shows normal distribution (Büyüköztürk, 2011; Küçüksille, 2008). Mahalanobis distance was used to detect the extreme values of the data.

As the number of independent variable is one (degree of freedom is accepted as one) it was compared with chi-square table value (6.6349) at 0.01 level. As a result, the highest value of Mahalanobis (5.5232) was found to be smaller than chi-square table value (6.6349). In this case, it can be said that there is not extreme value in data set (Çokluk, Şekercioğlu \& Büyüköztürk, 2014). To detect normal distribution and linearity, Scatter Plot Matrix is considered. That the scatter diagram of every variable couple is elliptical in Scatter Plot Matrix means that both normality and linearity are provided (Mertler \& Vannatta, 2005 cited by: Çokluk, Şekercioğlu \& Büyüköztürk, 2014). Scatter Plot Matrix in relation with the data is shown in figure 3.

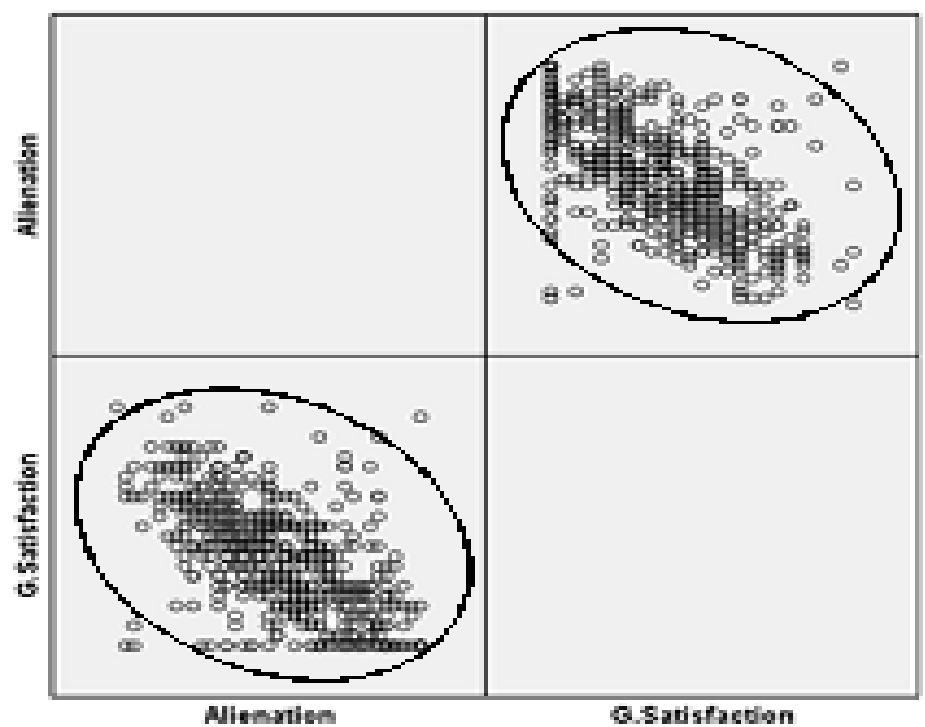

Figure 3. Scatter Plot Matrix of alienation and overall satisfaction 
Figure 3 shows that the combinations of binary variable are elliptical. Thus, it can be claimed that the data provide multivariable normal distribution and linearity.

The data were analyzed by structural equation modeling. AMOS 20 program was used in data analysis. In the evaluation of model goodness of fit, chi-square degree of freedom, ( $\varkappa 2 / \mathrm{sd}=\mathrm{CMIN} / \mathrm{DF})$ and significance level (p), root mean square error of approximation (RMSEA), goodness of fit index (GFI), adjusted goodness fit index (AGFI), comparative fit index (CFI) and normalized fit index (NFI) were considered. The values used in relation with model are shown in Table 1.

Table 1. Standard value ranges

\begin{tabular}{lll}
\hline Fit measurements & Acceptable Fit & Good Fit \\
& & \\
RMSEA & $.05<\mathrm{RMSEA} \leq .08$ & $0 \leq \mathrm{RMSEA} \leq .05$ \\
GFI & $.85 \leq \mathrm{GFI}<.89$ & $.90 \leq \mathrm{GFI} \leq 1.00$ \\
CFI & $.95 \leq \mathrm{CFI}<.97$ & $.97 \leq \mathrm{CFI} \leq 1.00$ \\
NFI & $.90 \leq \mathrm{NFI}<.94$ & $.94 \leq \mathrm{NFI} \leq 1.00$ \\
AGFI & $.85 \leq \mathrm{AGFI}<.90$ & $.90 \leq \mathrm{AGFI} \leq 1.00$ \\
$\mathbf{x} 2 /$ df & $3<x^{2} / \mathrm{df} \leq 5$ & $0 \leq \varkappa^{2} / \mathrm{df} \leq 3$ \\
\hline
\end{tabular}

Source: Meydan \& Sesen (2011).

In factor analysis, the low limit value of scale items factor load is accepted as 0.30 . The scale items are expected to have 0.30 and more factor load. Nevertheless, it is stated that the factor load value must be 0.40 even 0.45 and more, as well (Secer, 2013).

\section{Results and Discussions}

\subsection{Results}

A model was developed to determine the effect of university students' level of alienation on their perception of general satisfaction. The fit values of the model designed in accordance with the hypotheses of the study $\left(x^{2}=192.730 ; \mathrm{df}=87 ; \mathrm{p}=, 000 ; x 2 / \mathrm{df}=2.21 ; \mathrm{RMSEA}=0.04 ; \mathrm{CFI}=0.97 ; \mathrm{GFI}=0.95 ; \mathrm{AGFI}=0.94\right)$ are found to be within the range of accepted values. These results show that the model is significant. The model developed to determine the effect of university students' level of alienation on their perception of general satisfaction is shown in Figure 4.

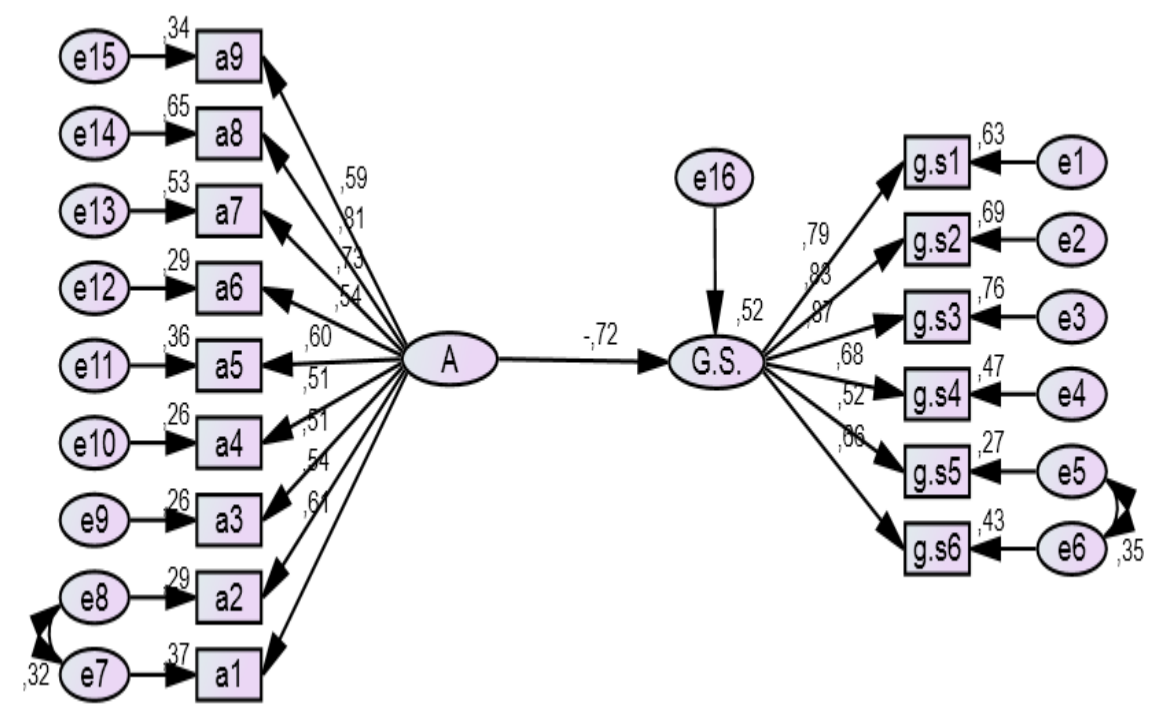

\section{A: Alieantion G.S.: General Satisfaction}

Figure 4. Structural equation modeling between alienation and general satisfaction 
Concerning Figure 4, while the viewed variables of alienation scale have factor loads ranging from 0.51 and 0.81 ; those of general satisfaction scale have 0.52 and 0.87 . Moreover, it can be inferred from Figure 4 that university students' level of alienation significantly affect their perception of general satisfaction in a negative way $(B=-0.72$; $\mathrm{p}<0.01$ ). This finding confirms $\mathrm{H}_{1}$ stating "the alienation level of university students effects their perception of general satisfaction in a negative way." On the other hand, the university students' level of alienation explains 52\% of their perception of general satisfaction (Figure 4). This finding confirms $\mathrm{H}_{2}$ which was "the alienation level of university students effects their perception of general satisfaction significantly."

\subsection{Discussion}

It was found in the current study that university students' level of alienation affects and explains their perception of general satisfaction in a negative way and significantly. This result confirms the hypotheses formed within the study. In related literature, it is stated that the concept alienation has a negative effect on students' individual life. For instance, Cabrera and Nora (1994) have shown that the alienation of students and their perception of discrimination and prejudice are strongly interrelated. Besides, a number of other studies have proved that student alienation (Hascher \& Hagenauer, 2010; Johnson, 2005) has a relation with academic success and school dropout.

As alienation causes erosion in traditional institutions such as family and school, (Bronfenbrenner, 1986 cited by Shoho, 1996), it causes erosion in students individually. Alienation involves sight blurriness and viewing the environment blurredly. Basically, both cases making the individuals discontent are not desirable. In this sense, it is possible to claim that there will be a decline in the satisfaction of an estranged individual. The same case is experienced concerning the result of the current study. Alienation diminishes the general satisfaction of students.

Alienation is a kind of disappointment (El-Mustafa, 2005). The possibility of a disappointed individual to be satisfied is quite low. It is quite possible for a student disappointed with social relations, peers, classroom and the teacher, to develop mental attrition in emotion and thought basis. In this sense, it can be claimed that it is of significant importance for the universities aiming at increasing general satisfaction of students to develop sustainable policies preventing alienation. It must be a priority for the universities to create an environment meeting the students' needs and keeping them away from alienation (Deep, 2012).

Mass media, peer pressure and the school suppresses the young's lives increasingly. As a result, the young experience emotional disasters, conflicts, and unstable values (Heath, 1970). These undesired attitude and behaviors faced by the young primarily weaken their ties to the life and lead dissatisfaction. Thus, qualitative applications are to be developed to minimize the harmful effect of alienation, one of the biggest problems in universities today, on students.

Students are significant stakeholders at universities (Wiers-Jenssen, Stensaker \& Grogaard, 2002) and the content of stakeholders for organizations is essential. The fundamental motto of various management approaches such as total quality management is customer satisfaction. It is too difficult for an organization stakeholders of which are dissatisfied to be long-termed. Within this scope, it is important for universities to take a step to satisfy their students who are among main stakeholders.

Russell (1994) after carrying out an experimental research conducted to minimize students' alienation from school, has reported that it is possible to take control of the school environment effecting student alienation while as for their relations with the peers it seems impossible (Simsek \& Akdemir, 2015). Hence, it can be claimed that it is important to realize supervisory applications minimizing alienation especially within university campuses. However, that does not indicate performing nothing for the peers. It is fundamental to organize seminar and conferences to increase the quality of interaction between peer groups.

\section{References}

Atas, O., Ayik, A. (2013). Öğretmen Adaylarında Okula Yabancılaşma: International Periodical For The Languages, Literature And History Of Turkish Or Turkic, 8(8), 103-122.

Avci, M. (2012). Eğitimde Temel Bir Sorun: Yabancılaşma. Atatürk Üniversitesi Sosyal Bilimler Enstitüsü Dergisi, 16 (3), 23-40

Bekhet, A. K., Elguenidi, M. \& Zausznıewsk1, J. A. (2011). The Effects Of Positive Cognitions On The Relationship Between Alienation And Resourcefulness İn Nursing Students İn Egypt. Journal Of Issues İn Mental Health Nursing, 32, 35-41. http://dx.doi.org/10.3109/01612840.2010.521618

Borden, V. M. (1995) Segmenting Student Markets With A Student Satisfaction And Priorities Survey, Research In Higher Education, 36(1), 73-88. 
Buyukozturk, S. (2011). Sosyal Bilimler İçin Veri Analizi El Kitabı. Ankara: Pegem Akademi.

Cabrera, A. F. \& Nora, A. (1994). College Students'perceptions Of Prejudice And Discrimination And Their Feelings Of Alienation:A Construct Validation Approach. The Review Of Education/Pedagogy/Cultural Studies. 16.

Caglar, C. (2012). Eğitim Fakültesi Öğrencilerinin Yabancılaşma Düzeyleri İle Öğretmenlik Mesleğine Yönelik Tutumları Arasındaki İlişki. Educational Sciences: Theory \& Practice, 13(3), 1497-1513.

Calabrese, R. L. \& Poe, J. (1990). Alienation: An Explanation Of High Dropout Rates Among African, American and Latino Students. Educational Research Quarterly, 14(4), 22-26.

Carrington, P. D. \& Conley, J. J. (1977). The Alienation of Law Students. Michigan Law Review, 75, No. 5/6, 887-899. http://dx.doi.org/10.2307/1288018

Case, J. M. (2008). Alienation And Engagement: Development Of An Alternative Theoretical Framework For Understanding Student Learning. Journal Of Higher Education, 55, 321-332. http://dx.doi.org/10.1007/s10734-007-9057-5

Cecen, A. R. (2006). School Alienation: Gender, Socio-Economic Status And Anger İn High School Adolescents. Educational Siences: Theory \& Practice, 6, 721-726.

Cokluk, O., Sekercioglu, G. \& Büyüköztürk, B. (2014). Sosyal Bilimler İçin Çok Değişkenli İstatistik Spss ve Lisrel Uygulamaları (II. Baskı). Ankara: Pegem Akademi.

Duru, E. (1995). Üniversite Öğrencilerinde Yabancılaşma ve Yalnızlık Düzeyi İlişkisi. (Yayınlanmamış Yüksek Lisans Tezi), Dokuz Eylül Üniversitesi/ Sosyal Bilimler Enstitüsü, İzmir.

El-Deep, H.A.E. (2012). Analytical Study Of Alienation Of Rural And Urban College Students İn Sharkia Governorate After The Revolution Of 25th Of January 2011. Australian Journal Of Basic And Applied Sciences, 6(8), 546-563.

Elliott, K. M. \& Shin, D. (2002). Student Satisfaction: An Alternative Approach To Assessing This İmportant Concept. Journal Of Higher Education Policy And Management, 24(2), 197-209. http://dx.doi.org/10.1080/1360080022000013518

El-Mustafa, A. (2005). Youth And The Crisis Of Social Alienation, A Seminar İn The Sixth Season Of Tuesday Cultural Forum. Al- Qatif, Saudi Arabia.

Erbas, M. K. (2014). The Relationship Between Alienation Levels Of Physical Education Teacher Candidates And Th Eir Att İtudes Towards The Teaching Profession. Australian Journal Of Teacher Education, 39(8). http://dx.doi.org/10.14221/ajte.2014v39n8.3

Erimez, C. (2012). Eğitim Fakültesi Öğrencilerinin Öğretmenlik Mesleğine Yönelik Tutumlarında Fakültelerine Yabancılaşmalarının Rolü. (Yayınlanmamış Yüksek Lisans Tezi), Mersin Üniversitesi /Eğitim Bilimleri Enstitüsü, Mersin.

Erjem, Y. (2005). Eğitimde Yabancılaşma Olgusu ve Öğretmen: Lise Öğretmenleri Üzerinde Sosyolojik Bir Araştırma. Türk Eğitim Bilimleri Dergisi, 3 (4).

Fromm, E. (1973). Çağımızın Özgürlük Sorunu. Bozkurt Güvenc (Çev.). Ankara: Özgür İnsan

Fromm, E. (2008). The Sane Society. New York: Rinehart

Gaidzanwa, R. B. (2007). Alienation, Gender and Institutional Culture at the University of Zimbabwe. Feminist Africa, 8. http://agi.ac.za/journal/feminist-africa-issue-8-2007-rethinking-universities

Hands, A. J. \& Warshak, R. A. (2011). Parental Alienation Among College Students. The American Journal Of Family Therapy, 39, 431-443. http://dx.doi.org/10.1080/01926187.2011.575336

Hascher, T. \& Hagenauer, H. (2010). Alienation From School. International Journal Of Educational Research, 49. http://dx.doi.org/10.1016/J.Ijer.2011.03.002

Heath, D. H. (1970). Student Alienation And School. The School Review, 4(7), 515-528. http://dx.doi.org/10.1086/442930

Hirschfeld, R. R. \& Feild, H. S. (2000).Work Centrality And Work Alienation: Distinct Aspects Of A General Commitment To Work. Journal of Organizational Behavior, 21. http://dx.doi.org/10.1002/1099-1379(200011)21:7<789::AID-JOB59>3.0.CO;2-W 
Hirschfeld, R. R., Feild, H. S. \& Bedeian, A.G. (2000).Work Alienation As An Individual-Difference Construct For Predicting Workplace Adjustment: A Test İn Two Samples. Journal Of Applied Social Psychology, 30 (9). http://dx.doi.org/10.1111/j.1559-1816.2000.tb02473.x

Hoy, W.K., Blazovsky, R. \& Newland, W, (1983). Bureaucracy And Alienation: A Comparative Analysis. Journal of Educational Administration, 21(2), 109 - 120. http://dx.doi.org/10.1108/eb009872

Kanungo, R. N. (1982). Work Alienation. New York: Praeger.

Karasar, N. (1995). Bilimsel Arastırma Yontemi. (19 Baskı). Ankara: Alkım

Korman, A. K., Wittig-Berman, U. \& Lang, D. (1981). Career Success And Personal Failure: Alienation İn Professionals And Managers. Academy Of Management Journal, 24 (2). http://dx.doi.org/10.2307/255846

Kucuksille, E. (2008). Parametrik Hipotez Testleri. Şeref Kalaycı (Ed.). SPSS Uygulamalı Çok Değişkenli İstatistik Teknikleri Ankara: Asil

Kurtulmus, M., Kacire, İ., Karabıyık, H. \& Yigit, B. (2015). Üniversite Yabancılaşma Ölçeği Geçerlik Güvenirlik Çalışması. Elektronik Ĕgitim Bilimleri Dergisi, 4(7), 100-110.

Lang, D. (1985). Preconditions Of Three Types Of Alienation İn Young Managers And Professionals. Journal Of Occupational Behavior, 6(3). http://dx.doi.org/10.1002/job.4030060302

Lewis, J. (2009). Social Alienation, Self-Efficacy, And Career Goals As Related To The Academic Performance Of College Sophomores. (Unpublished Doctoral Dissertation), Marywood University, USA.

Loo, C. M. \& Rolison, G. (1986). Alienation Of Ethnic Minority Students At A Predominantly White University. The Journal Of Higher Education, 57(1), 58-77. http://dx.doi.org/10.2307/1981466

Loughrey, M. E. \& Harris, M. B. (1992). Adolescent Alienation And Attitude Toward School in Native American, Hispanic And Anglo High School Students. Paper Presented At The Annual Meeting Of The American Educational Research Association, New York: (Erıc Document Reproduction Service No, 347027).

Mann, S. J. (2001). Alternative Perspectives On The Student Experience: Alienation And Engagement. Studies In Higher Education, Volume 26, No. 1. http://dx.doi.org/10.1080/03075070020030689

Mau, R. Y. (1992). The Validity And Devolution Of A Concept: Student Alienation. Journal Of Adolescence, 27, $721-741$

Meydan, C. H. \& Sesen, H. (2011). Yapısal Eşitlik Modellemesi Amos Uygulamaları. Ankara: Detay.

Moyer, T. R. \& Rolison, G. (1986). Alienation Of Ethnic Minority Students At A Predominantly Caucasian University. Journal Of Higher Education, 57(1), 58-77. http://dx.doi.org/10.2307/1981466

Neetler, G. (1957). A Measure Of Alienation. American Sociological Review. 22(6), 670-677. http://dx.doi.org/10.2307/2089196

Rafalides, M \& Hoy, W. K. (1971). Student Sense Of Alienation And Pupil Control Orientation Of High Schools. The High School Journal, 55, 101-111.

Roeser, R.W., Lord, S.E. \& Eccles, J. (1994). A portrait of academik alienation in adolescence: motivation, mental health, and family experience. http://www.rcgd.isr.umich.edu/garp/articles/eccles941.pdf

Secer, İ. (2013). Spss ve Lisrel Ille Pratik Veri Analizi. Ankara: Anı

Seeman M. (1959). On The Meaning Of Alienation. American Sociological Review, [University Of California, Los Angeles, Ca] 24:783-91. http://dx.doi.org/10.2307/2088565

Seeman, M. (1963). Alienation And Social Learning in A Reformatory. American Journal Of Sociology, 69 (3). http://dx.doi.org/10.1086/223585

Seeman, M. (1966). Alienation, Membership, And Political Knowledge: A Comparative Study. The Public Opinion Quarterly, 30 (3). http://dx.doi.org/10.1086/267429

Seidel, J. \& Vaughn, S. (1991). Social Alienation And The Learning-Disabled School Dropout. Learning Disabilities Research And Pratice, 6, 152-157.

Sheau-Yuen Yeo, M. A. (2006). Measuring Organizational Climate For Diversity: A Construct Validation Approach. (Unpublished Doctoral Thesis). The Ohio State University. Ohio. 
Shoho, A. R. (1996). The Alienation Of Rural Middle School Students: Implications For Gang Membership. Paper Presented At The Annual Meeting Of The American Educational Research Association, New York: (Eric Document Reproduction Service No, 396889).

Simsek, H. \& Atas Akdemir, Ö. (2015). Üniversite Öğrencilerinde Okula Yabancılaşma. Curr Res Educ (2015), 1(1) -1-12: http://dergipark.ulakbilim.gov.tr/article/download/5000136453/5000125310

Steward, R. J., Germain, S. \& Jackson, J. D. (1992). Alienation And İnteractional Style: A Study Of Successful Anglo, Asian Ve Hispanic University Students. Journal Of College Student Development, 33(2), 149-156.

Steward, R. J., Jackson, M. K. \& Jackson, J. K. (1990). Alienation And İnteractional Styles İn A Predominantly Caucasian Environment: A Study Of Successful Black Students. Journal Of College Student Development, 31(16), 59-515.

Suen, H. (1983). Alienation And Attrition Of Black College Students On A Predominantly White Campus. Journal Of College Student Personnel, 24, 117-121.

Tezcan, M. (1981). Egitim Sosyolojisi. (4.Bask1) Ankara: Ankara Üniversitesi.

Travis, J. E. (1995). Alienation From Learning: School Effects On Students. Journal Fro A Just And Caring Education, 1(4), 434-448.

Trompson, C. \& Fretz, B. R. (1991). Predicting The Adjustment Of Black Students At Predominantly White İnstitutions. Journal Of Higher Education, 62(2), 437-450. http://dx.doi.org/10.2307/1982004

Trusty, J. \& Dooley-Dickey, K. (1993). Alienation From School: An Exploratory Analysis Of Elementary And Middle School Students' Perceptions. Journal Of Research And Development İ Education, 26(4), $232-242$.

Valverde, S. A. (1987). A Comparative Study Of Hispanic High School Dropouts And Graduates: Why Do Some Leave School Early And Some Finish? Education And Urban Society, 19 (3), 320-329.

Wiers-Jenssen, J., Stensaker, B. \& Grogaard, J. B. (2002) Student Satisfaction: Towards an empirical deconstruction of the concept, Quality in Higher Education, 8:2, 183-195. http://dx.doi.org/10.1080/1353832022000004377

Yadaw, G. K. \& Nagle, Y. K. (2012). Work Alienation And Occupational Stress. Social Science International, 28 (2). 